\title{
Dye-Sensitized Nanocrystalline ZnO Solar Cells Based on Ruthenium(II) Phendione Complexes
}

\author{
Hashem Shahroosvand, ${ }^{1}$ Parisa Abbasi, ${ }^{1}$ \\ Mohsen Ameri, ${ }^{1}$ and Mohammad Reza Riahi Dehkordi ${ }^{2}$ \\ ${ }^{1}$ Chemistry Department, University of Zanjan, Zanjan, Iran \\ ${ }^{2}$ Laser Research Institute, Shahid Beheshti University, Evin, Tehran, Iran \\ Correspondence should be addressed to Hashem Shahroosvand, shahroos@znu.ac.ir
}

Received 24 July 2011; Revised 20 September 2011; Accepted 23 September 2011

Academic Editor: Newton Martins Barbosa Neto

Copyright (c) 2011 Hashem Shahroosvand et al. This is an open access article distributed under the Creative Commons Attribution License, which permits unrestricted use, distribution, and reproduction in any medium, provided the original work is properly cited.

\begin{abstract}
The metal complexes $\left(\mathrm{Ru}^{\mathrm{II}} \quad(\text { phen })_{2}(\right.$ phendione $\left.)\right)\left(\mathrm{PF}_{6}\right)_{2}(\mathbf{1}), \quad\left[\mathrm{Ru}^{\mathrm{II}} \quad\right.$ (phen) $($ bpy $)($ phendione $\left.)\right)\left(\mathrm{PF}_{6}\right)_{2} \quad(2), \quad$ and $\quad\left(\mathrm{Ru}^{\mathrm{II}}\right.$ $(\text { bpy })_{2}$ (phendione $)\left(\mathrm{PF}_{6}\right)_{2}(3)$ (phen $=1,10$-phenanthroline, bpy $=2,2^{\prime}$-bipyridine and phendione $=1,10$-phenanthroline5,6-dione) have been synthesized as photo sensitizers for $\mathrm{ZnO}$ semiconductor in solar cells. FT-IR and absorption spectra showed the favorable interfacial binding between the dye-molecules and $\mathrm{ZnO}$ surface. The surface analysis and size of adsorbed dye on nanostructure $\mathrm{ZnO}$ were further examined with AFM and SEM. The AFM images clearly show both, the outgrowth of the complexes which are adsorbed on $\mathrm{ZnO}$ thin film and the depression of $\mathrm{ZnO}$ thin film. We have studied photovoltaic properties of dye-sensitized nanocrystalline semiconductor solar cells based on $\mathrm{Ru}$ phendione complexes, which gave power conversion efficiency of $(\eta)$ of $1.54 \%$ under the standard AM 1.5 irradiation $\left(100 \mathrm{~mW} \mathrm{~cm}^{-2}\right)$ with a short-circuit photocurrent density $\left(J_{\mathrm{sc}}\right)$ of $3.42 \mathrm{~mA} \mathrm{~cm}^{-2}$, an open-circuit photovoltage $\left(V_{\mathrm{oc}}\right)$ of $0.622 \mathrm{~V}$, and a fill factor (ff) of 0.72 . Monochromatic incident photon to current conversion efficiency was $38 \%$ at $485 \mathrm{~nm}$.
\end{abstract}

\section{Introduction}

Dye-Sensitized Solar Cells (DSSCs) [1, 2] are attracting lot of interest because of their low cost and high efficiency. Many researchers have made efforts to modify the cell from various aspects to improve the DSSC efficiency. It is generally accepted that the dye-sensitized reaction step and electron injection step between the electrodes and the excited adsorbed dye are the key steps to control DSSCs efficiency [3-5]. For the optimization of the DSSCs components, that is, the different oxide semiconductor, the dye sensitizer and the electrolyte, exactitude in reporting the experimental procedures used is indispensable in order to compare the data between the many different laboratories active in this field $[6,7]$. Titanium dioxide advantages for sensitized photochemistry and photoelectrochemistry including a lowcost, widely available, nontoxic, and biocompatible material, and as such is even used in health care products as well as domestic applications such as paint pigmentation $[8,9]$. But, $\mathrm{TiO}_{2}$ films have a significant limitation that makes it difficult to grow on a substrate with controlled structure. This may prevent further development of DSSCs with $\mathrm{TiO}_{2}$ films. One-dimensionally ordered structures of metal oxides, such as rods or wires, will greatly improve DSSCs efficiency $[10,11]$. Therefore, extensive attention has been focused on looking for the suitable substitute for $\mathrm{TiO}_{2}$. Among these candidates, $\mathrm{ZnO}$ has been expected to be comparable to $\mathrm{TiO}_{2}$ because of its higher electronic mobility, similar energy level of the conduction band $[12,13]$, conductive crystal structure due to the anisotropic growth $[14,15]$, and its potential in high-area film morphologies [16]. $\mathrm{ZnO}$ is a versatile material that has a diverse group of morphologies; compared with nanocrystalline particle $\mathrm{ZnO}$ films, $\mathrm{ZnO}$ films containing vertically aligned nanorods $\mathrm{ZnO}$ film favor the electron transport due to the smoother electron transport channels and longer electron diffusion length [17-19].

However, the DSSC efficiency based on $\mathrm{ZnO}$ is much lower compared to that based on $\mathrm{TiO}_{2}$. One of the reasons for the relative low DSSC performance is due to the precipitation of the sensitizing dye with $\mathrm{Zn}$ cations on $\mathrm{ZnO}$ films [20]. 
On the other hand, much of the research in dye chemistry is devoted to the identification and synthesis of dyes matching the solar emission spectrum, while retaining stability in the photoelectrochemical environment. The anchoring groups of the dye ensure that it spontaneously assembles as a molecular layer upon exposing the oxide film to a dye solution. The best photovoltaic performance both in terms of conversion yield and long-term stability has so far been achieved with polypyridyl complexes of ruthenium and osmium. Sensitizers having the general structure $\mathrm{ML}_{2}(\mathrm{X})_{2}$ where $\mathrm{L}$ stands for 2,2-bipyridyl-4,4-dicarboxylic acid, $\mathrm{M}$ is $\mathrm{Ru}$ or $\mathrm{Os}$, and $\mathrm{X}$ presents a halide, cyanide, thiocyanate, acetyl acetonate, thiacarbamate, or water substituent, are particularly promising [21]. Several reports have already discussed the results obtained for ruthenium complexes having noncarboxylic acid anchoring group, such as phosphonic and catechol [22-28]. Among various kinds of polypyridily ligands, 1,10-phenanthroline-5,6-dione (phendione) is a versatile ligand for the assembly of metal organic materials [29-32]. This ligand has the ability to form stable complexes with a wide variety of metal ions and carries an o-quinone moiety. Metal complexes of this ligand potentially allow for the variation and control of redox properties over a wide range as well as the fine-tuning of potentials [33].

We reported a new class of complexes, (M(phendione)(L1)(L2)), where $\mathrm{M}=\mathrm{Os}(\mathrm{II}), \mathrm{Ru}(\mathrm{II}), \mathrm{Cu}(\mathrm{I})$, $\mathrm{L}_{1}, \mathrm{~L}_{2}=$ phen or bpy) as photosensitizers based on $\mathrm{TiO}_{2}$, $\mathrm{MoO}_{2}$ nanoparticles [34-36]. In this manuscript we design a new class of ruthenium phendione complexes, which have the carbonyl ligand as anchoring group based on $\mathrm{ZnO}$ nanoparticle. The dye-anchored $\mathrm{ZnO}$ surface was characterized by FT-IR, UV-visible, and AFM. The photovoltaic performances of phendione complexes based on $\mathrm{ZnO}$ have been studied.

\section{Experimental}

2.1. Materials and Physical Measurements. All chemicals and solvents were purchased from Merck \& Aldrich and used without further purification. UV-Vis spectra were recorded on an analytikjena SPECORD S1000 spectrometer with photodiode array detector. FT-IR spectra were recorded on a Shimatzu IR instrument, using $\mathrm{KBr}$ pellets. Atomic force microscopy (AFM) images of the samples were measured using an SPM (Digital Instruments, DME Software, Mahar Fan Abzar Co.) in the contact mode and stylus profilometry (Alpha-step 500). All scans were taken at room temperature in air. Imaging was performed using pyramidally shaped silicon nitride tips ( $4 \mu \mathrm{m}$ base, $4 \mu \mathrm{m}$ height, aspect ratio approximately $1: 1$, radius $<50 \mathrm{~nm}$ ) on silicon nitride cantilevers (typical spring constant $=0.032 \mathrm{~N} / \mathrm{m}$ ). In all the AFM scans, there are $512 \times 512$ data points across the areas of the scan and contact scans were made. The AFM is the preferred measurement technique as the force between the probe and the surface is much smaller (typically 10-9N) than for the stylus profilometer $(150 \mathrm{mN})$, and the tip has a much smaller radius of curvature (AFM $0.05 \mu \mathrm{m}$, profilometer $12.5 \mu \mathrm{m}$ ). Therefore the AFM results are more representative of the surface topography than those of the profilometer and also have a greater sensitivity, with the ability to measure height variations of $0.1 \mathrm{~nm}$ with a horizontal resolution of $<4 \mathrm{~nm}$.

Photoelectrochemical measurements employed the dyesensitized $\mathrm{ZnO}$ film incorporated into a thin-layer sandwichtype solar cell. A light-reflecting counter electrode was employed, consisting of a conducting zinc oxide-coated glass onto which a $2 \mathrm{pm}$ thick Pt mirror had been deposited by sputtering. The counter electrode was placed directly on top of the dye-coated transparent $\mathrm{ZnO}$ film, supported by the conducting glass sheet. Both electrodes were clamped tightly together. The dye-coated $\mathrm{ZnO}$ film was illuminated through the conducting glass support, a $1000 \mathrm{~W}$ Xe lamp. The shortcurrent measurement was performed using a potentiostat model CMBP-1. The intensity of the light was calibrated using a model OM-1001C radiometer/photometer.

\subsection{Synthesis}

2.2.1. Preparation of $R u$ (II) Phendione Complexes. The Complexes $\left(\mathrm{Ru}^{\mathrm{II}} \text { (phen }\right)_{2}$ (phendione) $)\left(\mathrm{PF}_{6}\right)_{2}$; (Anal. Calcd: C, 44.96; H, 2.30; N, 8.73; found: C, 44.92; H, 2.29; N, $8.70)$ and $\left(\mathrm{Ru}^{\mathrm{II}}\right.$ (bpy) ${ }_{2}$ (phendione) $)\left(\mathrm{PF}_{6}\right)_{2}$ (Anal. Calcd: C, 42.06; H, 2.50; N, 9.19; found: C, 44.89; H, 2.49; N, 9.15); were synthesized following the procedure of Goss and Abruna [29]. The ( $\mathrm{Ru}^{\mathrm{II}}$ (phen) $(\mathrm{bpy})$ (phendione) $)\left(\mathrm{PF}_{6}\right)_{2}$ (Anal. Calcd: C, 43.55; H, 2.36; N, 8.96; found: C, 43.50; $\mathrm{H}, 2.32 ; \mathrm{N}, 8.90)$ complex was prepared, using the same procedure except using $1 \mathrm{~mol}$ phen and $1 \mathrm{~mol}$ bpy instead of 2 mol phen.

2.2.2. Preparation of $\mathrm{ZnO}$ Nanoparticle Film. Fisher microscope glass slides were used as substrates; $\mathrm{ZnO}$-coated glass films already were boiled in deionized (DI) water for 0.5 hour, then ultrasonically cleaned in acetone and alcohol solution $(1: 1 \mathrm{v}: \mathrm{v})$ for 1 hour, and finally dried in oven at $100^{\circ} \mathrm{C}$ for 3 hours.

Film substrates were secured, conductive side up to a piece of white paper with electrode surface. The cellophane tape served to mask an area of the film for ohmic contact to the contactive glass. Typically the $\mathrm{ZnO}$, geometric area was $1 \mathrm{~cm}$.

After the pretreatment, these slides were ready for the following chemical bath deposition. The chemical bath was prepared from $15 \mathrm{~mL}$ of $0.15 \mathrm{~mol} / \mathrm{L}$ zinc acetate dihydrate $\left(\mathrm{Zn}\left(\mathrm{CH}_{3} \mathrm{COO}\right)_{2} \cdot 2 \mathrm{H}_{2} \mathrm{O}\right)$ methanol solution. Following deposition for 30 hours at $60^{\circ} \mathrm{C}$, the as-synthesized films were annealed at $200^{\circ} \mathrm{C}$ for $5 \mathrm{~min}$ and then at $450^{\circ} \mathrm{C}$ for $15 \min [44]$.

2.2.3. Surface Attachment of Dyes. The Ru phendione complexes were dissolved in dehydrated ethanol with a concentration of $0.25 \mathrm{M}$. $\mathrm{ZnO}$ nanoparticle film was immersed into the solution of each complex and maintained at $40^{\circ} \mathrm{C}$ for over $18 \mathrm{~h}$ to coordinate complex on the $\mathrm{ZnO}$ surface [45]. During this time the film surface charges to the brown that is the color of the attached dyes. After adsorption, $\mathrm{ZnO}$ films with $\mathrm{Ru}$-phendione dyes were withdrawn from the solution and dried in air. 


\section{Results and Discussion}

The Chemical structures of synthesized complexes were shown in Figure 1.

3.1. FT-IR and UV-Vis Absorption Measurements. The Fourier transform IR (FT-IR) spectroscopy has been shown to be a powerful tool for extracting structural information of the molecules adsorbed onto a $\mathrm{ZnO}$ surface.

The (FT-IR) spectra of complexes measured as a powder show the most prominent band at approximately $1700 \mathrm{~cm}^{-1}$ in all of the complexes which is assigned to $\mathrm{C}=\mathrm{O}$ stretching wave number of the coordinated phendione ligand [46]. In case of the attachment of the dye molecules on $\mathrm{ZnO}$, the oxygen of carbonyl group would be coordinated to $\mathrm{ZnO}$; therefore, we expected the $\mathrm{C}=\mathrm{O}$ stretch band to be shifted to lower wavelength.

FT-IR spectra of phendione complexes (1) and phendione dye adsorbed $\mathrm{ZnO}$ films (2) are shown in Figure 2. Adsorption band at $1700 \mathrm{~cm}^{-1}$ in spectrum (1) and $1670 \mathrm{~cm}^{-1}$ in spectrum (2) corresponds to the $\mathrm{C}=\mathrm{O}$ and $\mathrm{C}-\mathrm{O}$ stretching from carbonyl group before and after dye adsorption on $\mathrm{ZnO}$ surface, respectively. FT-IR spectrum of dyeadsorbed $\mathrm{ZnO}$ films (2) also was shown $\mathrm{Zn}-\mathrm{O}$ stretching at $530 \mathrm{~cm}^{-1}$.

The diffuse reflectance IR spectra of complexes as shown above anchored to $\mathrm{ZnO}$ film are listed in Table 1.

The possible binding modes for Ru polypyrydine complexes containing carbonynl groups on $\mathrm{ZnO}$ surface are shown in Scheme 1.

If the difference between the carbonyl group stretching mode band in the adsorbed state is less than that in the free solid state, then, the anchoring mode is either bridging bidentate (II) or chelation (III), and if the opposite applies, then, the anchoring mode is unidentate.

The unidentate coordination of the carbonyl group removes the equivalence of the two oxygen atoms, resulting in an ether type of bond formation between the carbonyl group and the $\mathrm{ZnO}$ surface and also free carbonyl in dye.

The FT-IR spectra of the adsorbed Ru polypyridine complexes (1)-(3) on $\mathrm{ZnO}$ film do not exhibit typical free carbonyl starching modes; thus this type of coordination can be ruled out, leaving only two possibilities, bridging bidentate mode (II) or chelation mode (III).

Unidentate mode (I) is also reported by Li et al. [23] for phendione complexes. In this work, they suggested that the $\mathrm{C}=\mathrm{O}$ stretch band observed at a lower wavelength than that of the phendion complexes in $\mathrm{KBr}$ pellets was ascribed to the shift caused by the contribution in the formation of the unidentate bond between the dye molecules and $\mathrm{TiO}_{2}$ surface. Comparing our obtained data from IR spectra $\left(520 \mathrm{~cm}^{-1}\right)$ with $\mathrm{Zn}-\mathrm{O}$ band in the chelating mode (III) and the bridging-bidenate mode (II) available in reported data [46] suggests that our results are closer to chelating mode (III) and the bridging-bidenate mode is unexpected. Therefore, the carbonyl groups are probably bound to the $\mathrm{ZnO}$ surface via a chelating mode (III).

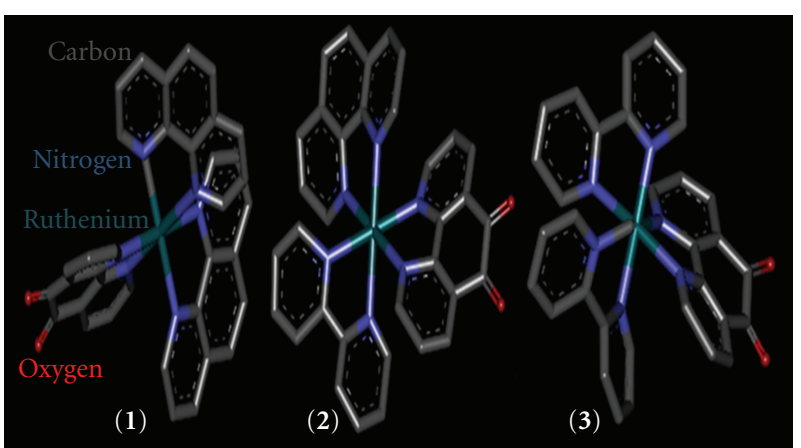

FIGURE 1: The chemical structures of synthesized complexes $\left(\mathrm{Ru}^{\mathrm{II}}\right.$ $(\text { phen })_{2}$ (phendione $\left.)\right)^{2+}(\mathbf{1}),\left(\mathrm{Ru}^{\mathrm{II}}\right.$ (phen $)($ bpy $)($ phendione $\left.)\right)^{2+}(\mathbf{2})$, and $\left(\mathrm{Ru}^{\mathrm{II}}(\mathrm{bpy})_{2} \text { (phendione) }\right)^{2+}(\mathbf{3})$.

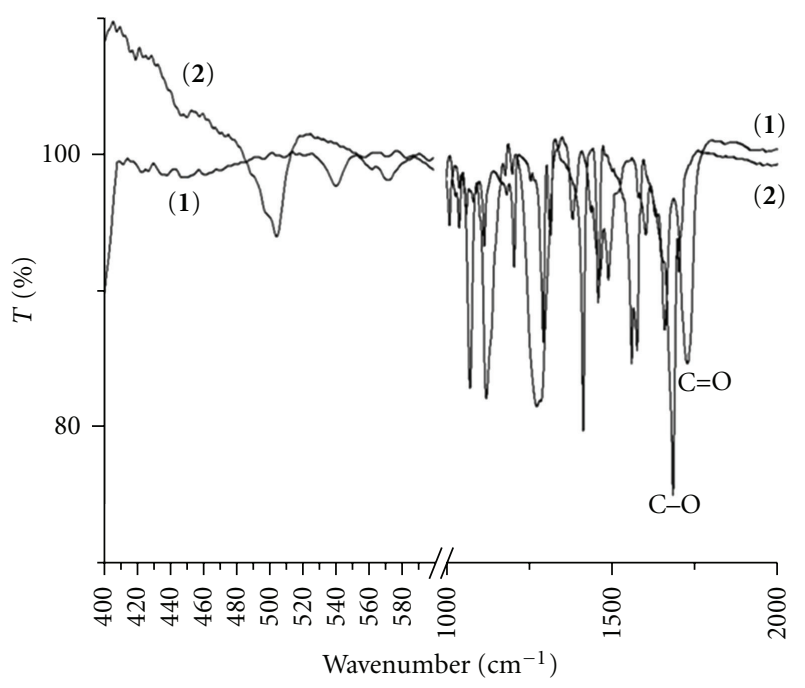

FIGURE 2: FT-IR spectra of phendione complexes (1) and phendione complexes adsorbed $\mathrm{ZnO}$ films (2).

The absorption spectra of the dye based on $\mathrm{ZnO}$ nanoparticle are compared with the solution spectra in Figure 3.

These complexes show broad and strong visible bands around $450-470 \mathrm{~nm}$ regions due to metal-to-ligand charge transfer (MLCT) transitions. Two distinct absorption bands in the UV region are due to the ligands $\pi \rightarrow \pi^{*}$ transitions.

As shown in Figure 3, one can observe that the absorption band in visible region is shifted to short wavelength (blue shift) and its intensity is enhanced comparing to the complexes which are not adsorbed to $\mathrm{ZnO}$ nanoparticle (Table 2). These results indicate that the charge transfer interaction is responsible for binding the ruthenium complexes on $\mathrm{ZnO}$ film. There are reports that when carboxylic acid group as anchoring group is adsorbed on metal oxides, absorption bands shifted to long wavelength (red shift) [10, $11,47]$. On the other hand, when changing from the carbonyl groups to the carboxylic ones, that is, from electron-acceptor to electron-donor, absorption band apparently shifted from short wavelength to long one. The blue shift in UV-vis spectra in the MLCT bands of phendione complexes is already observed [23]. 
TABLE 1: Electronic ${ }^{\mathrm{a}}$ and Infrared ${ }^{\mathrm{b}}$ data for the dyes ${ }^{\mathrm{c}}$ and dyes on $\mathrm{ZnO}$ surface ${ }^{\mathrm{d}}$.

\begin{tabular}{|c|c|c|c|c|c|}
\hline Dye & MLCT $^{\mathrm{c}}$ & MLCT $^{\mathrm{d}}$ & $v(\mathrm{C}=\mathrm{O})^{\mathrm{c}}$ & $v(\mathrm{C}-\mathrm{O})^{\mathrm{d}}$ & $v(\mathrm{Zn}-\mathrm{O})^{\mathrm{d}}$ \\
\hline (1) & $467(2.4)$ & $420(3.4)$ & 1700 & 1670 & 520 (broad) \\
\hline (2) & $465(2.3)$ & $420(3.3)$ & 1702 & 1667 & 523 (broad) \\
\hline (3) & $460(2.3)$ & $415(3.1)$ & 1697 & 1665 & 515 (broad) \\
\hline
\end{tabular}

${ }^{\mathrm{a}} \lambda$ in $\mathrm{nm}(\log \varepsilon)$ in ethanol solution.

bIR data $(\mathrm{KBr})$ in $\mathrm{cm}^{-1}$.

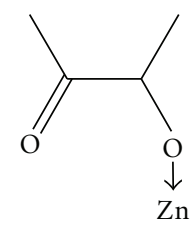

Unidenate (I)

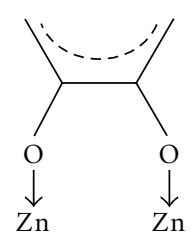

Bridging-bidenate (II)

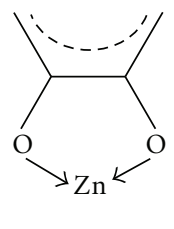

Chelating (III)

Scheme 1: The possible binding modes for the carbonynl groups of phendion molecule with $\mathrm{ZnO}$.

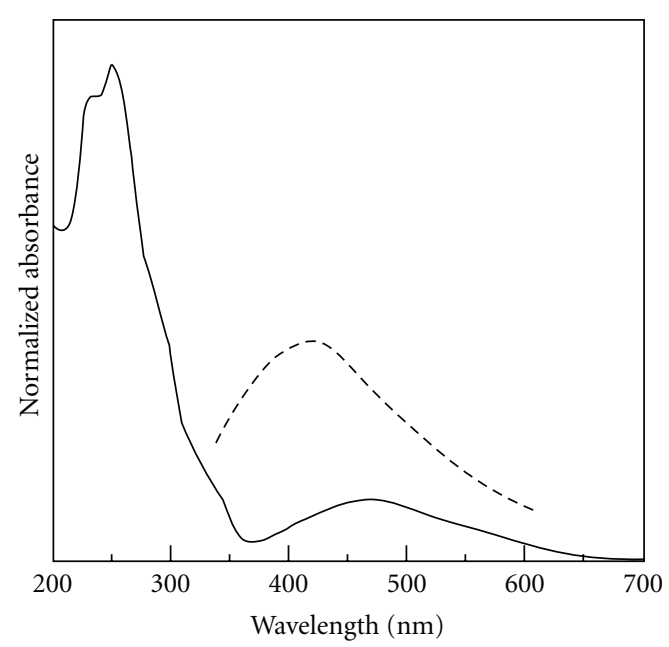

(a) Dye (1)

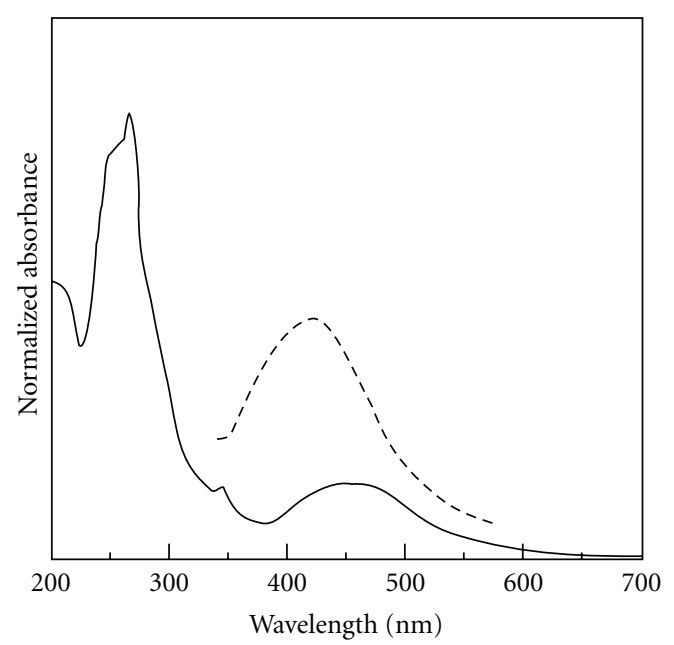

(b) Dye (2)

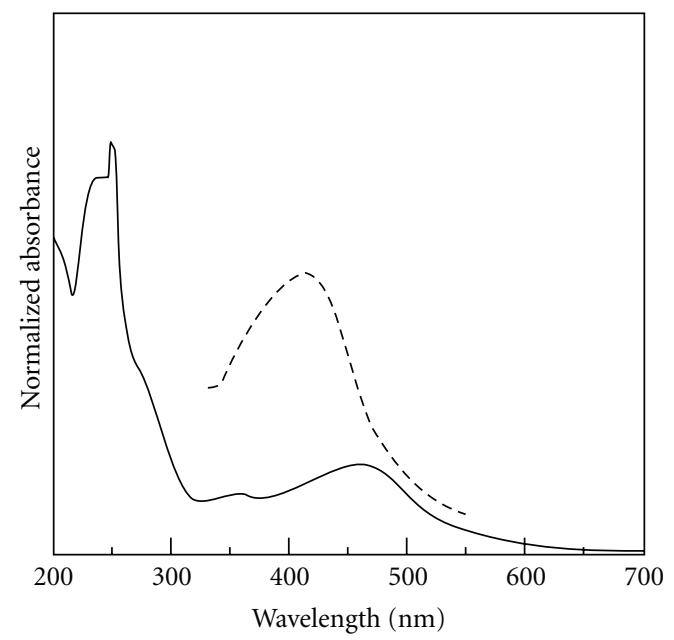

(c) Dye (3)

FIGURE 3: Absorption spectra of dye (1) (solid line) in ethanol and adsorbed on ZnO film (dashed line) (a), dye (2) in ethanol (solid line) and adsorbed on $\mathrm{ZnO}$ film (dashed line) (b), and absorption spectra of dye (3) (solid line) in ethanol and adsorbed on $\mathrm{ZnO}$ film (dashed line) (c). 
TABLE 2: Photocurrent performance data obtained with ruthenium photosensitizer with noncarboxylic acid anchoring group ligand [39].

\begin{tabular}{|c|c|c|c|c|c|c|c|}
\hline Dye & $V_{\mathrm{oc}}(\mathrm{V})$ & $I_{\mathrm{SC}}\left(\mathrm{mA} \mathrm{cm}^{-2}\right)$ & $\operatorname{IPCE}_{\max }(\%)$ & $\mathrm{ff}$ & $\eta_{\text {cell }}(\%)$ & & Ref \\
\hline$\left(\mathrm{Ru}\left(\mathrm{ttp}-\mathrm{PO}_{3} \mathrm{H}_{2}\right)(\mathrm{dmbpy})(\mathrm{NCS})\right)$ & 0.653 & 4.73 & 75.6 & 0.705 & & $\mathrm{TiO}_{2}$ & {$[22]$} \\
\hline $\mathrm{Ru}\left(\mathrm{bpy}-\left(\mathrm{PO}_{3} \mathrm{H}_{2}\right)_{2}\right)_{2} \mathrm{NCN}_{2}$ & 0.490 & 5 & 75 & 0.67 & & $\mathrm{TiO}_{2}$ & {$[40]$} \\
\hline$\left(\mathrm{Ru}(\mathrm{bpy})_{2}(\mathrm{pySH})_{2}\right)$ & 0.019 & 0.036 & 2.9 & & & $\mathrm{ZnO}$ & {$[41]$} \\
\hline$\left(\mathrm{Ru}(\mathrm{bpy})_{2}\left(\mathrm{pyS}^{-}\right)_{2}\right)$ & 0.0321 & 0.045 & 5.6 & & & $\mathrm{ZnO}$ & {$[41]$} \\
\hline$\left(\mathrm{Ru}(\mathrm{bpy})_{2}\right.$ (phendione) $) \mathrm{PF}_{6}$ & & & 34 & & & $\mathrm{TiO}_{2}$ & [23] \\
\hline$\left(\mathrm{Ru}(\mathrm{bpy})_{2}\right.$ (phendioxime) $) \mathrm{PF}_{6}$ & & & 27 & & & $\mathrm{TiO}_{2}$ & {$[23]$} \\
\hline$\left(\operatorname{Ru}(\mathrm{bpy})_{2}(\mathrm{NCS})\right)$ & 0.36 & 1.2 & & 0.5 & 0.34 & $\mathrm{TiO}_{2}$ & {$[42]$} \\
\hline$\left(\mathrm{Ru}(\mathrm{dmbpy})_{2}(\mathrm{bpy}-\mathrm{acac})\right) \mathrm{PF}_{6}$ & 0.487 & 2.02 & 0.292 & & & $\mathrm{TiO}_{2}$ & {$[43]$} \\
\hline$\left(\mathrm{Ru}(\mathrm{bpy})_{2}\left(\mathrm{bpy}-\mathrm{CH}_{2} \mathrm{COOLi}\right)\right) \mathrm{PF}_{6}$ & 0.245 & 0.83 & $34 \pm 5$ & & & $\mathrm{TiO}_{2}$ & {$[24]$} \\
\hline$\left(\operatorname{Ru}(\text { phen })_{2}(\text { phendione })\right)^{2+}$ & 0.622 & 3.42 & 38 & 0.72 & 1.54 & $\mathrm{ZnO}$ & Our work \\
\hline$(\mathrm{Ru}($ phen$) \mathrm{bpy})($ phendione $))^{2+}$ & 0.619 & 3.37 & 36.5 & 0.71 & 1.51 & $\mathrm{ZnO}$ & Our work \\
\hline$\left(\operatorname{Ru}(\text { bpy })_{2}(\text { phendione })\right)^{2+}$ & 0.618 & 3.33 & 36 & 0.69 & 1.495 & $\mathrm{ZnO}$ & Our work \\
\hline
\end{tabular}

Based on literature [48], if the absorption coefficient of the dye itself can be enhanced, the enhancement of the conversion efficiency of DSCCs will be expected.

The broadening of the absorption band is also beneficial in extending the photoresponse of $\mathrm{ZnO}$. These changes let us use the phendione complexes implanted on $\mathrm{ZnO}$ in solar cells.

3.2. Atomic Force Microscopy (AFM) and Scanning Electron Microscopy (SEM) Measurements. The surface analysis of products was further examined with AFM.

A medium-scale image $(10 \times 10 \mu \mathrm{m})$ gathered by AFM on the dried complex (1) adsorbed on $\mathrm{ZnO}$ is shown in Figure 4(a).

To clarify the different regions of layered structure, some parts of Figure 4(a) are expanded with different resolution magnitudes and represented in Figure 4 (b) $(2.47 \times$ $2.47 \mu \mathrm{m})$, Figure $4(\mathrm{c})(2.45 \times 2.45 \mu \mathrm{m})$, Figure $4(\mathrm{~d})(1 \times$ $1 \mu \mathrm{m})$, Figure $4(\mathrm{f})(348 \times 348 \mathrm{~nm})$, and Figure $4(\mathrm{e})(276 \times$ $276 \mathrm{~nm})$.

In all of the zoomed images, one can be $\mathrm{ZnO}$ molecules packed in an irregular spongy pattern with nanoporous sizes. The light points of image are shown as adsorbed complex on $\mathrm{ZnO}$ nanoparticle film. In fact, light in the topographic images corresponds to a high value of surface free energies. These results indicate that the layered structure is composed of the alternation of adsorbed complex on $\mathrm{ZnO}$ and $\mathrm{ZnO}$ nanoparticles.

Figures 4(e) and 4(f) represent the zoomed images of Figure $4(\mathrm{~d})$. These images show that the particle size of the adsorbed complex is about $46.5 \mathrm{~nm}$ and the size of one of the pores is about $24 \mathrm{~nm}$.

Figure 5 shows Scanning electron microscopy of $\mathrm{ZnO}$ nanoparticle before (A) and after absorption with dye (1). The specimen surface in Figure 5(a) appears nanoparticles with about $50 \mathrm{~nm}$. From the SEM image, we can see that the $\mathrm{ZnO}$ film is uniform and compact on the glass substrate. In presence of dye (Figure 5(b)), the data gave the surface of $\mathrm{ZnO}$ surface with absence of porous and large aggregation of particles. The surface of $\mathrm{ZnO}$ film has been covered with many aggregated particles (Figure 5(b)). Comparing this SEM image with the $\mathrm{ZnO}$ film before dye adsorption, we believe that these particles are aggregated phendione dye. It is well known that dye aggregation in $\mathrm{ZnO}$ is one of the major problems of the dye adsorption process, which decreases the consequent DSSCs efficiency [13]. One of the main tasks of this work is to solve the dye aggregation problem.

3.3. Photovoltaic Performance. Photovoltaic performance of nanocrystalline oxide semiconductor $\mathrm{ZnO}$ solar cells sensitized by phendione complexes photosensitizer under the standard AM 1.5 irradiation $\left(100 \mathrm{~mW} \mathrm{~cm}^{-2}\right)$ is shown in Table 2. Also, photocurrent performance data for ruthenium complexes with noncarboxylic acid anchoring polypyridines, in dye-sensitized solar cell, are listed in Table 2, where $J_{\mathrm{sc}}$ is the short-circuit photocurrent density, $V_{\mathrm{oc}}$ is open-circuit photovoltage, $\mathrm{ff}$ is the fill factor, and $\eta$ is solar energy to current conversion efficiency.

These semiconductor films were almost transparent because large semiconductor particles were not included as a scattering center. The electrolyte solution was a mixture of $0.6 \mathrm{M}$ DMPImI, $0.1 \mathrm{M} \mathrm{LiI}, 0.05 \mathrm{M} \mathrm{I}_{2}$, and $0.5 \mathrm{M}$ TBP in methoxyacetonitrile.

A typical photocurrent-voltage curve for the $(\mathrm{Ru} \text { (phen })_{2}$ (phendione $\left.)\right)^{2+}(\mathbf{1})$ solar cell under standard AM 1.5 irradiation $\left(100 \mathrm{~mW} \mathrm{~cm}^{-2}\right)$ is shown in Figure 6. Solar energy to electricity conversion efficiency, $\eta$, of $1.54 \%$ was attained with $J_{\mathrm{sc}}$ of $3.42 \mathrm{mAcm}^{-2}, V_{\mathrm{oc}}$ of $0.622 \mathrm{~V}$, and $\mathrm{ff}$ of 0.72 .

Figure 7 shows monochromatic incident photon to current conversion efficiency with the nanocrystalline $\mathrm{ZnO}$ solar cell sensitized by $\left(\mathrm{Ru}(\text { phen })_{2}\right.$ (phendione) $) \mathrm{PF}_{6}(\mathbf{1})$ with the electrolyte of $0.6 \mathrm{MDMPImI}, 0.1 \mathrm{MLiI}, 0.05 \mathrm{MI}_{2}$, and $0.5 \mathrm{M}$ TBP in methoxyacetonitrile (solid line). IPCE is represented as a function of wavelength. $\mathrm{Ru}(\mathrm{deeb})(\mathrm{bpy})_{2}{ }^{2+} / \mathrm{TiO}_{2}$ in $0.5 \mathrm{M} \mathrm{LiClO}_{4} / 0.05 \mathrm{M} \mathrm{I}_{2}$ electrolyte. The $\mathrm{TiO}_{2}$ surfaces were pretreated with $\mathrm{pH} 2$ (circles) aqueous solution [37]. $\mathrm{Ru}$ (deeb) $)_{2}(\mathrm{py})_{2} / \mathrm{TiO}_{2}$ (squares) and $\mathrm{Ru}(\text { bpy })_{2}(\mathrm{ina})_{2} / \mathrm{TiO}_{2}$ (triangles) regenerative solar cell in $0.5 \mathrm{M} \mathrm{LiI} / 0.05 \mathrm{M} \mathrm{I}_{2}$ acetonitrile electrolyte [38] where py is pyridine, ina is 


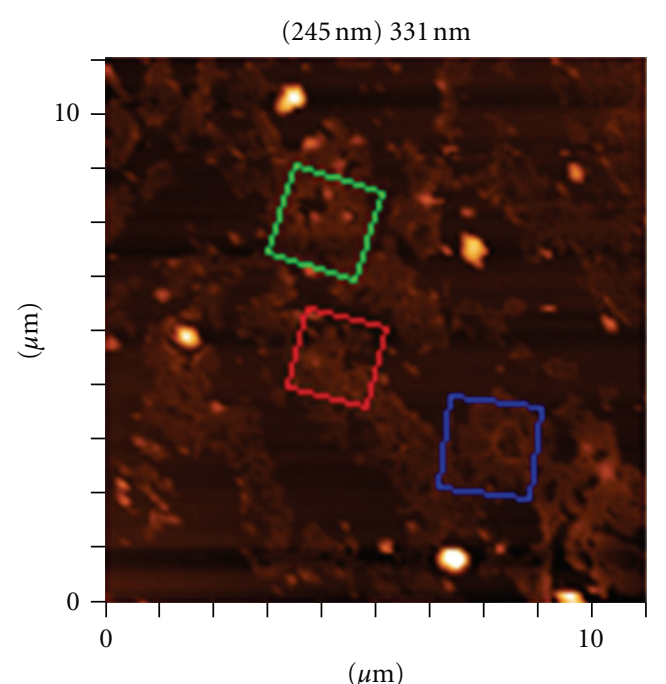

(a)

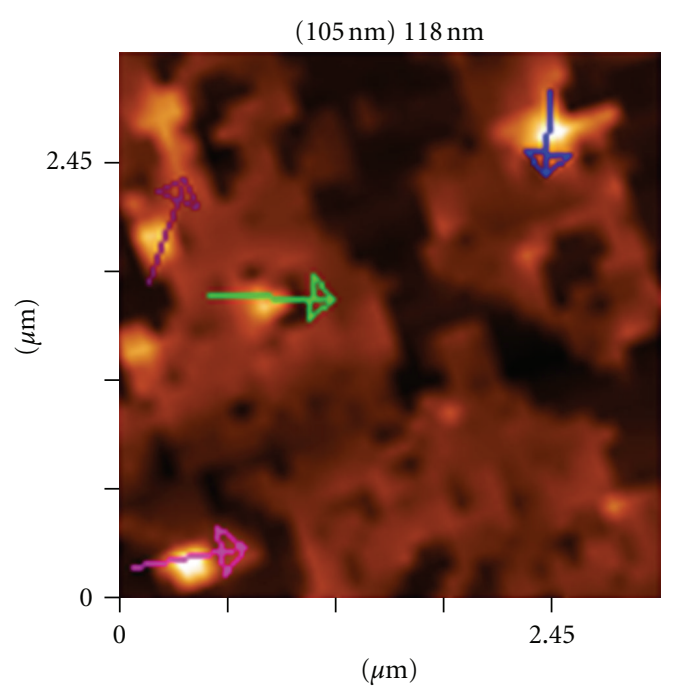

(c)

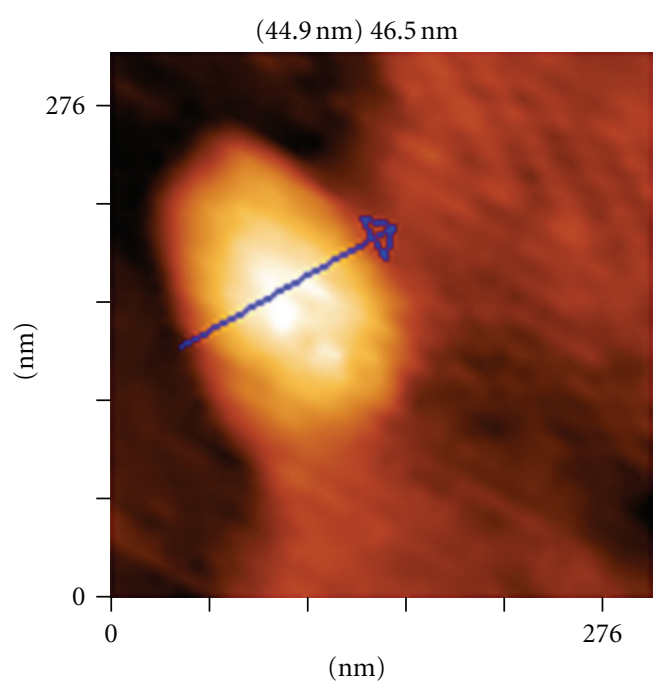

(e)

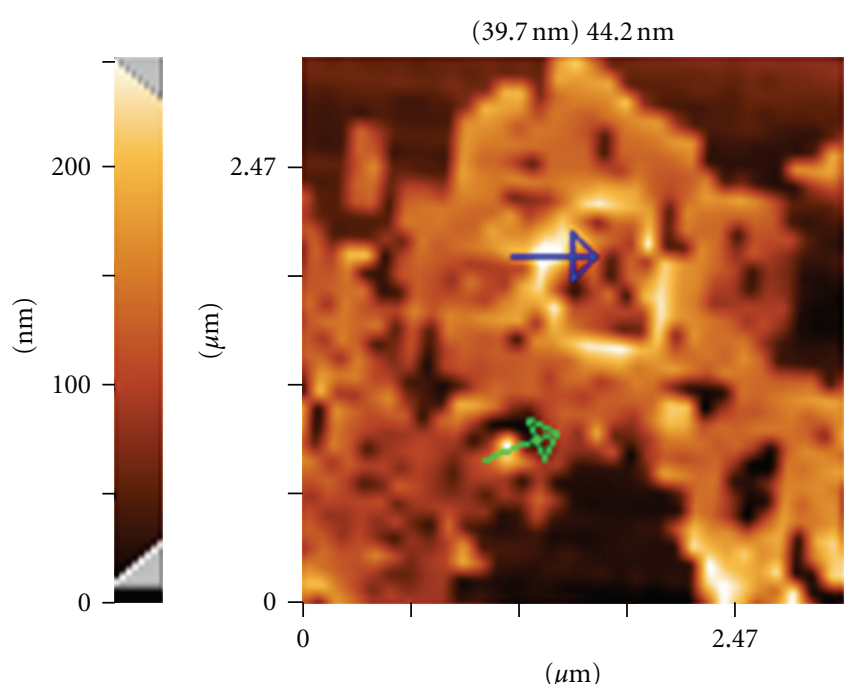

(b)
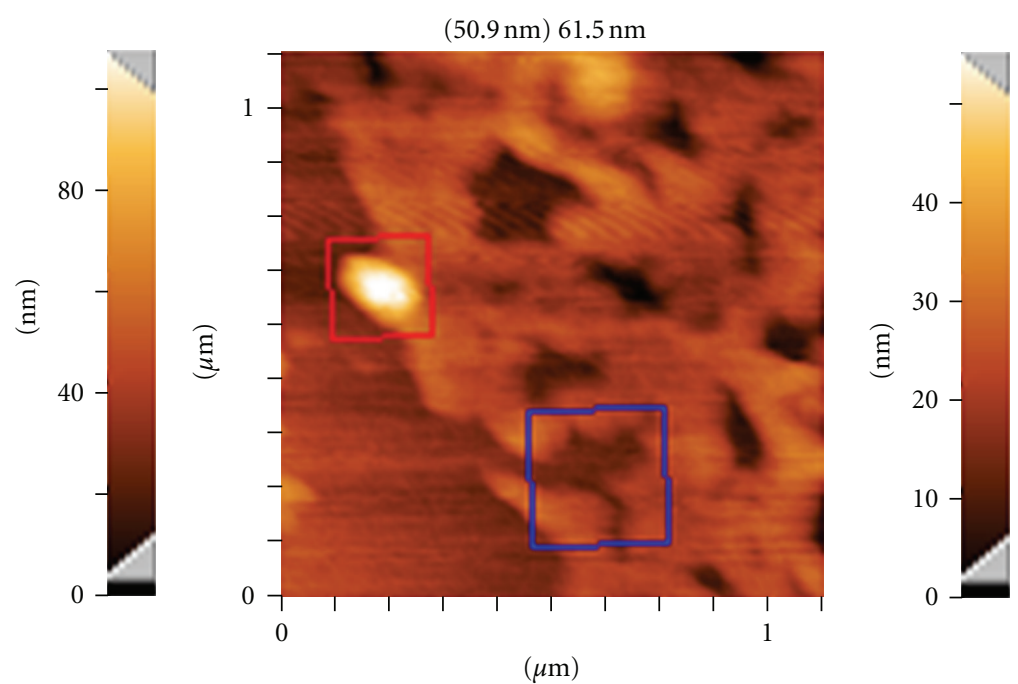

(d)
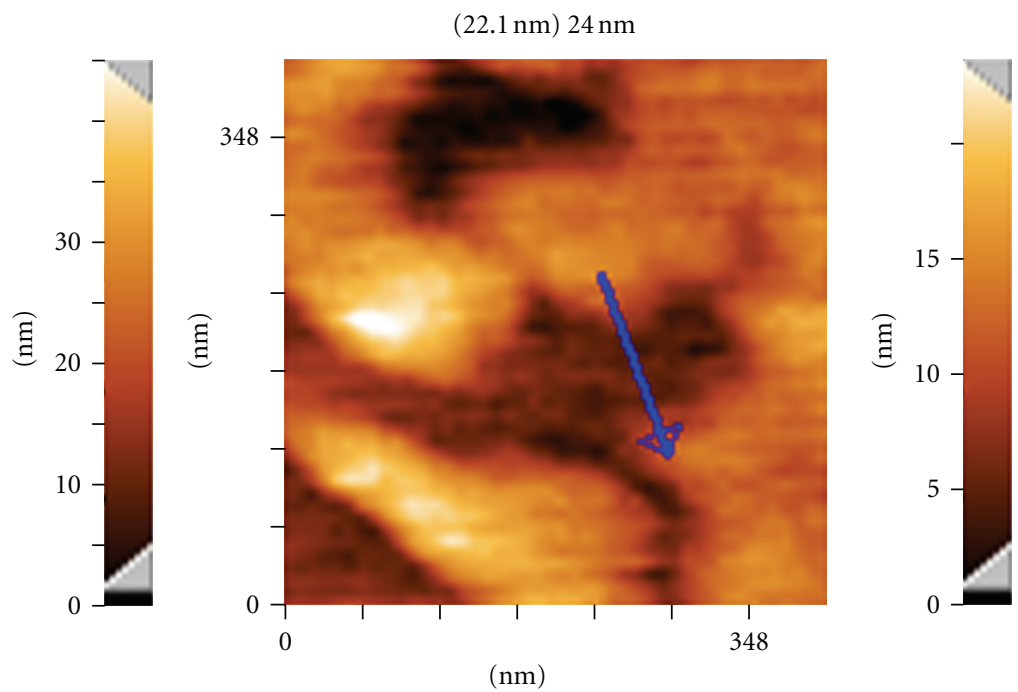

FIgURE 4: AFM topographic images of absorbed phendione complex (1) on the thin film of $\mathrm{ZnO}$ nanoparticles. 


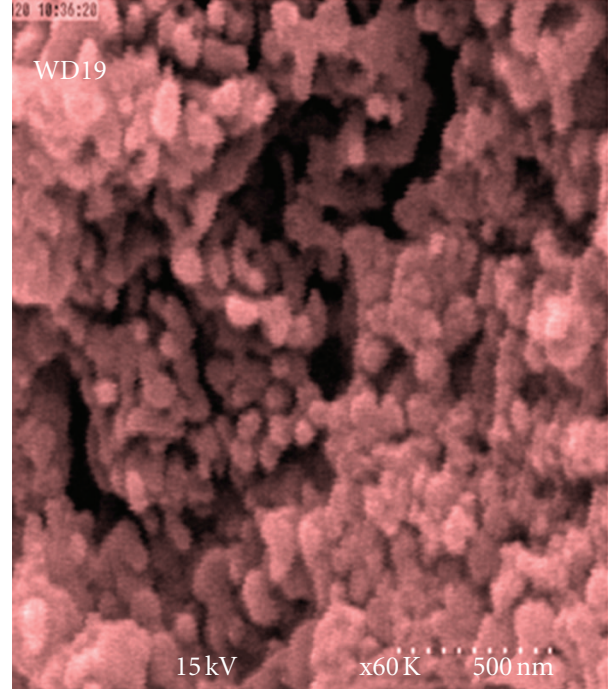

(a)

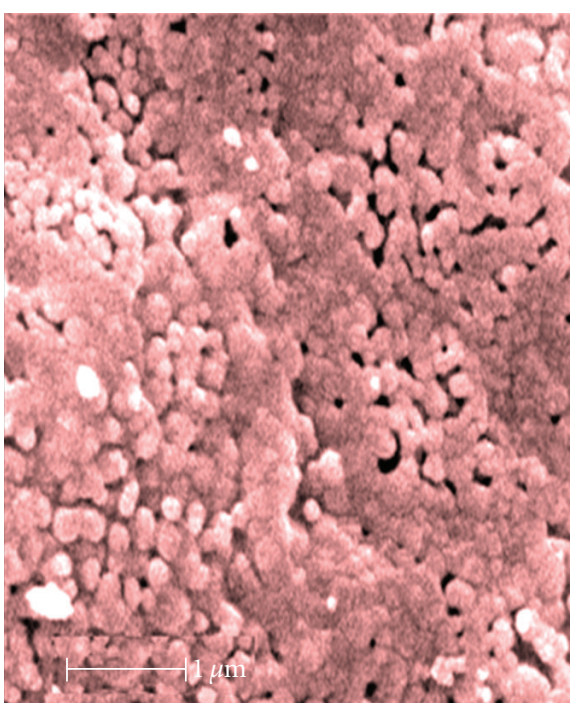

(b)

FIgURE 5: Scanning electron microscopy (SEM) of $\mathrm{ZnO}$ nanparicle (a) and adsorbed dye on $\mathrm{ZnO}$ film (b).

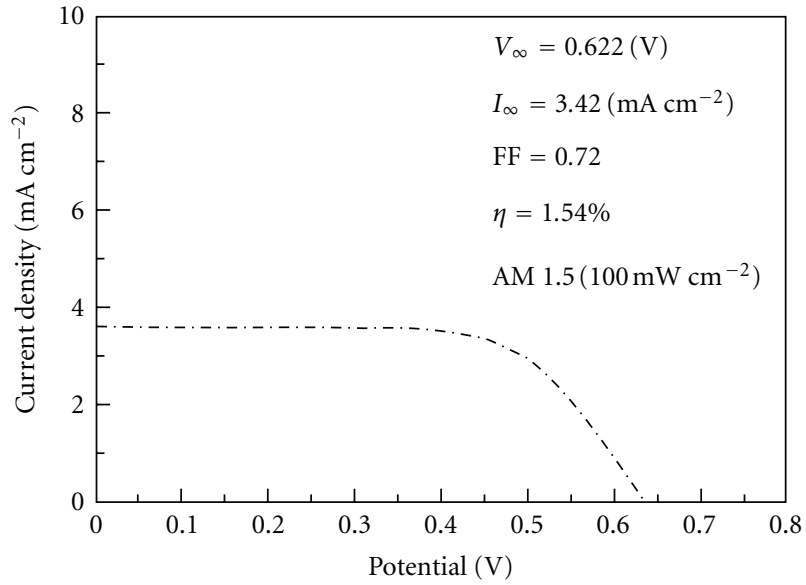

Figure 6: Typical photocurrent-voltage curve for the $(\mathrm{Ru} \text { (phen })_{2}$ (phendione) $)^{2+}(\mathbf{1})$ sensitized $\mathrm{ZnO}$ solar cell under the standard AM 1.5 irradiation $\left(100 \mathrm{~mW} \mathrm{~cm}^{-2}\right) . \eta$ is $1.54 \%$ with $J_{\text {sc }}$ of $3.42 \mathrm{~mA} \mathrm{~cm}^{-2}, V_{\text {oc }}$ of $0.622 \mathrm{~V}$, and ff of 0.72 .

isonicotinic acid, deeb is $4,4^{\prime}-\left(\mathrm{CO}_{2} \mathrm{Et}\right)_{2}-2,2^{\prime}$-bipyridine, deeb is $4,4^{\prime}-\left(\mathrm{CO}_{2} \mathrm{Et}\right)_{2}$-bpy, and dcb- $\mathrm{H}_{2}$ is $4,4^{\prime}-\left(\mathrm{CO}_{2} \mathrm{H}\right)_{2}$-bpy. $\left(\mathrm{Ru}(\text { phen })_{2}\right.$ (phendione) $) \mathrm{PF}_{6}$ (1) sensitizer converts visible light at $400-500 \mathrm{~nm}$ to current with a maximum efficiency of $38 \%$ at $485 \mathrm{~nm}$. To compare the IPCE between Ru phendione complexes and the same structures, it is useful to note that the $\mathrm{Qu}$ et al. [37] reported the photocurrent action spectra of $\mathrm{TiO}_{2}$ surfaces pretreated at $\mathrm{pH}=1,2,5$, and 11 sensitized with $\mathrm{Ru}(\mathrm{deeb})-(\mathrm{bpy})_{2}{ }^{2+}$ in either $0.5 \mathrm{M} \mathrm{TBAI} / 0.05 \mathrm{M} \mathrm{I}_{2}$ or $0.5 \mathrm{M} \mathrm{LiI} / 0.05 \mathrm{M} \mathrm{I}_{2}$ acetonitrile electrolyte. With TBAI $/ \mathrm{I}_{2}$, the $\mathrm{pH}=1$ and $\mathrm{pH}=2$ acid-pretreated surfaces demonstrated high incident IPCE $45 \%$ and $70 \%$, respectively, while the $\mathrm{pH}$ $=5$ and $\mathrm{pH}=11$ pretreated samples gave very small IPCE $4 \%$ and $2 \%$, respectively. With LiI in the electrolyte, the IPCE of $\mathrm{pH}=5$ and $\mathrm{pH}=11$ pretreated $\mathrm{TiO}_{2}$ was dramatically

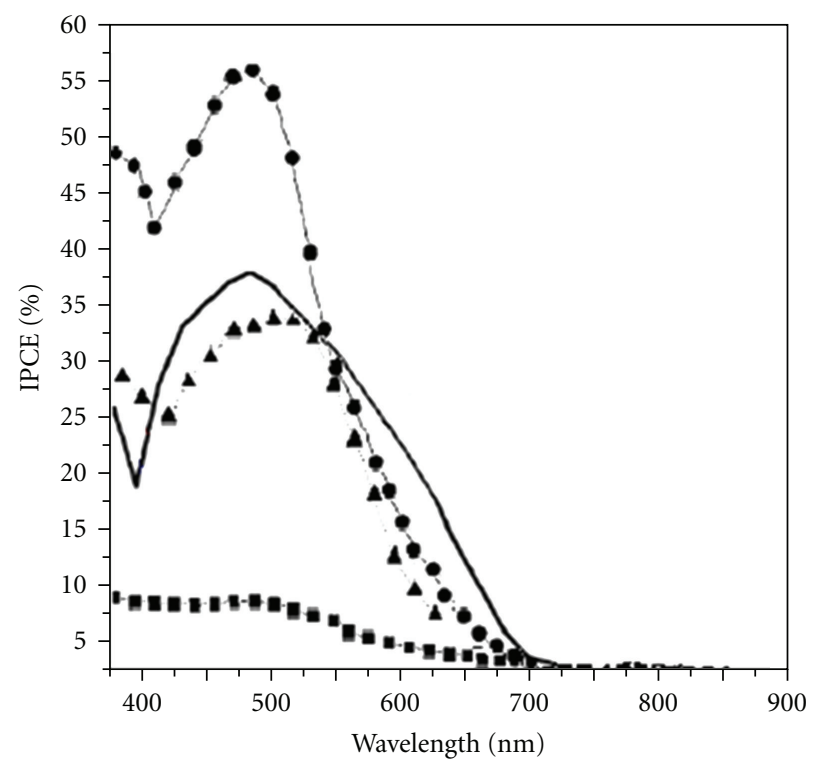

Figure 7: Photocurrent action spectrum obtained with the nanocrystalline $\mathrm{ZnO}$ solar cell sensitized by $\left(\mathrm{Ru}(\text { phen })_{2}(\text { phendione })\right)^{2+}(\mathbf{1})$ with the electrolyte of $0.6 \mathrm{M}$ DMPImI, 0.1 M LiI, 0.05 $\mathrm{M} \mathrm{I}_{2}$, and $0.5 \mathrm{M} \mathrm{TBP}$ in methoxyacetonitrile (solid line) and $\mathrm{Ru}\left(\right.$ deeb) $(\mathrm{bpy})_{2}{ }^{2+} / \mathrm{TiO}_{2}$ in $0.5 \mathrm{MLiClO}_{4} /$ $0.05 \mathrm{M} \mathrm{I}_{2}$ electrolyte. The $\mathrm{TiO}_{2}$ surfaces were pretreated with $\mathrm{pH} 2$ (circles) aqueous solution [37]. Ru- (deeb $)_{2}(\mathrm{py})_{2} / \mathrm{TiO}_{2}$ (squares) and $\mathrm{Ru}(\mathrm{bpy})_{2}(\mathrm{ina})_{2} / \mathrm{TiO}_{2}$ (triangles) are regenerative solar cell in $0.5 \mathrm{M} \mathrm{LiI} / 0.05 \mathrm{M} \mathrm{I}_{2}$ acetonitrile electrolyte [38]. IPCE is represented as a function of wavelength.

improved, 54\% and 27\%, respectively. The IPCE for the $\mathrm{pH}=1$ and $\mathrm{pH}=2$ pretreated samples is also high as $30 \%$ and $57 \%$, respectively. Photocurrent action spectra, for $\mathrm{Ru}(\text { bpy })_{2}(\text { ina })_{2} / \mathrm{TiO}_{2}$ and $\mathrm{Ru}(\text { deeb })_{2}(\mathrm{py})_{2} / \mathrm{TiO}_{2}$ in a $0.5 \mathrm{M}$ $\mathrm{LiI} / 0.05 \mathrm{M} \mathrm{I}_{2}$ acetonitrile electrolyte measured at room temperature, are calculated as $33 \%$ and $3 \%$, respectively. So, in 
comparison with our results, the IPCE decreased in the order $\mathrm{Ru}(\mathrm{dcb})(\mathrm{bpy})_{2} / \mathrm{TiO}_{2}=\mathrm{Ru}($ deeb $)(\mathrm{bpy})_{2} / \mathrm{TiO}_{2}$ in low $\mathrm{pH}>$ $\mathrm{Ru}$-phendione complexes $/ \mathrm{ZnO}>\mathrm{Ru}(\text { bpy })^{2-}(\text { ina })_{2} / \mathrm{TiO}_{2}>$ $\mathrm{Ru}(\text { deeb })_{2}(\mathrm{py})_{2} / \mathrm{TiO}_{2}$.

As mentioned in Table 2, the best performance for ruthenium complexes with noncarboxylic acid was obtained with phosphonic terpyridine complexes with IPCE values up to $70 \%$; these appear to be promising candidates to compete with carboxylated analogous [49]. These new photosensitizers exhibit intense, broad MLCT absorption, covering a wide range of visible light.

The rate of electron transport in $\mathrm{Ru}$ phendione complexes is a major element of the overall efficiency of the cells. The electrons, injected into the conduction band from optically excited complex, can traverse the $\mathrm{ZnO}$ network and be collected at the transparent conducting glass or can react with a redox mediator. The reaction of conduction band electrons with a redox mediator gives undesirable dark currents reducing significantly the charge-collection efficiency and thereby decreasing the total efficiency of the cell. The binding coordination of the complex on the $\mathrm{ZnO}$ and $\mathrm{TiO}_{2}$ surfaces is almost the same $[10,11]$. Photovoltaic performance of the $\mathrm{Ru}-(\mathrm{dcbpy})_{2}(\mathrm{NCS})_{2} / \mathrm{ZnO}$ (where the ligand dcbpy $=4,4^{\prime}$-dicarboxy-2,2'-bipyridine) solar cell is inferior to that of the $\mathrm{Ru}(\mathrm{dcbpy})_{2}(\mathrm{NCS})_{2} / \mathrm{TiO}_{2}$ solar cell [5052].

To obtain clear view about limitations and advantages of $\mathrm{Ru}$ phendione complexes/ $\mathrm{ZnO}$ rather than the other dyes/semiconductors, it is important to note that dependence of photocurrent performance on semiconductor materials, $\mathrm{TiO}_{2}>\mathrm{ZnO}>\mathrm{SnO}_{2}>\operatorname{In}_{2} \mathrm{O}_{3}[10,11]$, is mainly due to two suggested cases, first, differences in the conduction band levels of semiconductors, and/or second, the aggregation of dye on the semiconductor electrode. [51, 53]. In the first case, Asbury et al. [53] observed much slower electron injection from $\mathrm{Ru}(\mathrm{dcbpy})_{2}(\mathrm{NCS})_{2}$ in $\mathrm{ZnO}$ compared to that in $\mathrm{TiO}_{2}$ by femtosecond mid-IR absorption spectroscopy. They suggested that different electron injection kinetics in $\mathrm{Ru}(\text { dcbpy })_{2}(\mathrm{NCS})_{2} / \mathrm{ZnO}$ and $\mathrm{Ru}(\mathrm{dcbpy})_{2}(\mathrm{NCS})_{2} / \mathrm{TiO}_{2}$ solar cells may be due to the difference in electronic coupling between the $\pi^{*}$ orbital of the dye and accepting orbital in $\mathrm{ZnO}$ and $\mathrm{TiO}_{2}$ and/or their density of states. The states near the conduction band edge of $\mathrm{ZnO}$ consist of $4 \mathrm{~s}$ orbitals of $\mathrm{Zn}^{2+}$, while those of $\mathrm{TiO}_{2}$ consist of $3 \mathrm{~d}$ orbitals of $\mathrm{Ti}^{4+}$, resulting in a difference in electronic coupling with the $\pi^{*}$ orbital of the dye.

In the second, based on literature [51], protons derived from the Ru-complexes containing carboxylic acid groups make the dye-loading solution relatively acidic and dissolve $\mathrm{ZnO}$, which generate $\mathrm{Zn}^{2+}$ /dye aggregates. Such aggregates are harmful to the cells, because they can reduce the electron injection efficiencies and fill nanoscale pores of the $\mathrm{ZnO}$ photoanodes.

Our data clearly indicate that phendione complexes as photosensitizes are adsorbed on $\mathrm{ZnO}$ nanoparticle and solve the problem of $\mathrm{ZnO}$ aggregation. We conclude that dyephendione complexes, which neither produce solution acidic nor dissolve $\mathrm{ZnO}$, are able to improve efficient electron injection into the semiconductor conduction band.

\section{Conclusion}

In summary, we fabricated a new binding state useful for attachment of Ru phendione complexes onto nanocrystallin $\mathrm{ZnO}$ surface. IR, UV-visible spectra, and AFM images supported favorable interfacial binding between the dye molecules, and $\mathrm{ZnO}$, surface, the decrease IR absorption owing to the $\mathrm{C}=\mathrm{O}$ stretch mode, and the effective red shift in UV-vis spectra in MLCT bands supported the formation of the chelating linkage on dye-anchored $\mathrm{ZnO}$ films. The $\mathrm{Ru}$ phendione complexes used in this study show suitable properties for solar energy conversion applications. The relatively improvement in the overall solar cell efficiency in the present work originates from a controlled dyesensitization procedure thorough avoiding dye aggregation.

However, the overall efficiency is still much lower, due to lack of absorption in the visible and near IR regions. Thus, the challenges to reach the results reported on dye $\mathrm{Ru}$ carboxylated $/ \mathrm{TiO}_{2}$ systems remain. Further work on phendione complexes is in progress, and we believe that improvement can be accomplished by a thorough replacement of attached functionalized groups to phendione complexes. Moreover, to fundamentally understand how differences in nanostructured films, for example, conductivity, affect the photoconversion efficiency, a more detailed investigation of different particle sizes, film thickness, and film morphology needs to be done.

\section{Acknowledgments}

Thanks are extended to Professor K. Nazeeruddin from EPFL for proofreading the original manuscript and his useful comments. Also, the authors thank Zanjan University for financial supports and Laser Research Institute of Shahid Beheshti University for technical supports.

\section{References}

[1] B. O’Regan and M. Grätzel, "A low-cost, high-efficiency solar cell based on dye-sensitized colloidal $\mathrm{TiO}_{2}$ films," Nature, vol. 353, no. 6346, pp. 737-740, 1991.

[2] M. Grätzel, "Photoelectrochemical cells," Nature, vol. 414, no. 6861, pp. 338-344, 2001.

[3] M. K. Nazeeruddin, A. Kay, I. Rodicio et al., "Conversion of light to electricity by cis- $\mathrm{X}_{2}$ bis $\left(2,2^{\prime}\right.$-bipyridyl- $4,4^{\prime}$ dicarboxylate)ruthenium(II) charge-transfer sensitizers ( $\mathrm{X}=$ Cl-, Br-, I-, CN-, and SCN-) on nanocrystalline $\mathrm{TiO}_{2}$ electrodes," Journal of the American Chemical Society, vol. 115, no. 14, pp. 6382-6390, 1993.

[4] C.-S. Chou, C.-M. Hsiung, C.-P. Wang, R.-Y. Yang, and M.G. Guo, "Preparation of a counter electrode with p-type nio and its applications in dye-sensitized solar cell " International Journal of Photoenergy, vol. 2010, Article ID 902385, 9 pages, 2010.

[5] G.-Y. Chen, M.-W. Lee, and G.-J. Wang, "Fabrication of dyesensitized solar cells with a 3D nanostructured electrode," International Journal of Photoenergy, vol. 2010, Article ID 585621, 7 pages, 2010.

[6] S. Ito, T. N. Murakami, P. Comte et al., "Fabrication of thin film dye sensitized solar cells with solar to electric power 
conversion efficiency over 10\%," Thin Solid Films, vol. 516, no. 14, pp. 4613-4619, 2008.

[7] E. Figgemeier and A. Hagfeldt, "Are dye-sensitized nanostructured solar cells stable? An overview of device testing and component analyses," International Journal of Photoenergy, vol. 6, no. 3, pp. 127-140, 2004.

[8] M. Grätzel, "Dye-sensitized solar cells," Journal of Photochemistry and Photobiology C, vol. 4, no. 2, pp. 145-153, 2003.

[9] Y.-C. Liu, Y.-F. Lu, Y.-Z. Zeng, C.-H. Liao, J.-C. Chung, and T.-Y. Wei, "Nanostructured mesoporous titaniumdioxide thin filmprepared by sol-gelmethod for dye-sensitized solar cell," International Journal of Photoenergy, vol. 2011, Article ID 619069, 9 pages, 2011.

[10] J. N. De Freitas, V. C. Nogueira, B. I. Ito et al., "Dye-sensitized solar cells and solar module using polymer electrolytes: stability and performance investigations," International Journal of Photoenergy, vol. 2006, Article ID 75483, 6 pages, 2006.

[11] K. Hara, H. Sugihara, Y. Tachibana et al., "Dye-sensitized nanocrystalline $\mathrm{TiO}_{2}$ solar cells based on ruthenium(II) phenanthroline complex photosensitizers," Langmuir, vol. 17, no. 19, pp. 5992-5999, 2001.

[12] K. Kakiuchi, E. Hosono, and S. Fujihara, "Enhanced photoelectrochemical performance of $\mathrm{ZnO}$ electrodes sensitized with N-719," Journal of Photochemistry and Photobiology A, vol. 179, no. 1-2, pp. 81-86, 2006.

[13] C. Bauer, G. Boschloo, E. Mukhtar, and A. Hagfeldt, "Electron injection and recombination in $\mathrm{Ru}$ (dcbpy)2(NCS) 2 sensitized nanostructured ZnO," Journal of Physical Chemistry B, vol. 105, no. 24, pp. 5585-5588, 2001.

[14] M. Law, L. E. Greene, J. C. Johnson, R. Saykally, and P. Yang, "Nanowire dye-sensitized solar cells," Nature Materials, vol. 4, no. 6, pp. 455-459, 2005.

[15] K. Tennakone, P. V. V. Jayaweera, and P. K. M. Bandaranayake, "Dye-sensitized photoelectrochemical and solid-state solar cells: charge separation, transport and recombination mechanisms," Journal of Photochemistry and Photobiology A, vol. 158, no. 2-3, pp. 125-130, 2003.

[16] A. B. F. Martinson, J. E. McGarrah, M. O. K. Parpia, and J. T. Hupp, "Dynamics of charge transport and recombination in $\mathrm{ZnO}$ nanorod array dye-sensitized solar cells," Physical Chemistry Chemical Physics, vol. 8, no. 40, pp. 4655-4659, 2006.

[17] B. Cao, X. Teng, S. H. Heo et al., "Different $\mathrm{ZnO}$ nanostructures fabricated by a seed-layer assisted electrochemical route and their photoluminescence and field emission properties," Journal of Physical Chemistry C, vol. 111, no. 6, pp. 2470-2476, 2007.

[18] L. E. Greene, M. Law, D. H. Tan et al., "General route to vertical $\mathrm{ZnO}$ nanowire arrays using textured $\mathrm{ZnO}$ seeds," Nano Letters, vol. 5, no. 7, pp. 1231-1236, 2005.

[19] R. Könenkamp, K. Boedecker, M. C. Lux-Steiner et al., "Thin film semiconductor deposition on free-standing $\mathrm{ZnO}$ columns," Applied Physics Letters, vol. 77, no. 16, pp. 2575$2577,2000$.

[20] H. Horiuchi, R. Katoh, K. Hara et al., "Electron injection efficiency from excited $\mathrm{N} 3$ into nanocrystalline $\mathrm{ZnO}$ films: effect of $\left(\mathrm{N} 3-\mathrm{Zn}^{2+}\right)$ aggregate formation," Journal of Physical Chemistry B, vol. 107, no. 11, pp. 2570-2574, 2003.

[21] M. Grätzel, "Conversion of sunlight to electric power by nanocrystalline dye-sensitized solar cells," Journal of Photochemistry and Photobiology A, vol. 164, no. 1-3, pp. 3-14, 2004.

[22] B. Jing, H. Zhang, M. Zhang, Z. Lu, and T. Shen, "Ruthenium(II) thiocyanate complexes containing 4'-(4phosphonatophenyl )-2,2' $56^{\prime}, 2^{\prime \prime}$-terpyridine: synthesis, pho- tophysics and photosensitization to nanocrystalline $\mathrm{TiO}_{2}$ electrodes," Journal of Materials Chemistry, vol. 8, no. 9, pp. 2055-2060, 1998.

[23] M. Li, Z. Xiao, Z. Huan, and Z. Lu, "New binding state useful for attachment of dye-molecules onto $\mathrm{TiO}_{2}$ surface," Applied Surface Science, vol. 125, no. 2, pp. 217-220, 1998.

[24] V. Aranyos, H. Grennberg, S. Tingry, S. E. Lindquist, and A. Hagfeldt, "Electrochemical and photoelectrochemical investigation of new carboxylatobipyridine (bisbipyridine)ruthenium(II) complexes for dye-sensitized $\mathrm{TiO}_{2}$ electrodes," Solar Energy Materials and Solar Cells, vol. 64, no. 2, pp. 97-114, 2000.

[25] O. Schwarz, D. Van Loyen, S. Jockusch, N. J. Turro, and H. Dürr, "Preparation and application of new ruthenium(II) polypyridyl complexes as sensitizers for nanocrystalline $\mathrm{TiO}_{2}$," Journal of Photochemistry and Photobiology A, vol. 132, no. 1-2, pp. 91-98, 2000.

[26] Y. Yang, J. Tao, X. Jin, and Q. Qin, "New microporous polymer electrolyte based on polysiloxane grafted with imidazoliumiodide moieties for DSSC," International Journal of Photoenergy, vol. 2011, Article ID 405738, 9 pages, 2011.

[27] S. A. Trammell, J. A. Moss, J. C. Yang et al., "Sensitization of $\mathrm{TiO}_{2}$ by phosphonate-derivatized proline assemblies," Inorganic Chemistry, vol. 38, no. 16, pp. 3665-3669, 1999.

[28] C. R. Rice, M. D. Ward, M. K. Nazeeruddin, and M. Gratzel, "Catechol as an efficient anchoring group for attachment of ruthenium-polypyridine photosensitisers to solar cells based on nanocrystalline $\mathrm{TiO}_{2}$ films," New Journal of Chemistry, vol. 24, no. 9, pp. 651-652, 2000.

[29] C. A. Goss and H. D. Abruna, "Spectral, electrochemical, and electrocatalytic properties of 1,10-phenanthroline-5,6-dione complexes of transition metals," Inorganic Chemistry, vol. 24, no. 25, pp. 4263-4267, 1985.

[30] G. A. Shabir and N. J. Forrow, "Validation of a reversed-phase HPLC method for 1,10-phenanthroline-5,6-dione and analysis of its impurities by HPLC-MS," Journal of Pharmaceutical and Biomedical Analysis, vol. 33, no. 2, pp. 219-230, 2003.

[31] F. Calderazzo, G. Pampaloni, and V. Passarelli, "1,10Phenanthroline-5,6-dione as a building block for the synthesis of homo- and heterometallic complexes," Inorganica Chimica Acta, vol. 330, no. 1, pp. 136-142, 2002.

[32] N. Margiotta, V. Bertolasi, F. Capitelli et al., "Influence of steric and electronic factors in the stabilization of five-coordinate ethylene complexes of platinum(II): X-ray crystal structure of [PtCl2(2,9-dimethyl-1,10-phenanthroline-5,6-dione)]," Inorganica Chimica Acta, vol. 357, no. 1, pp. 149-158, 2004.

[33] T. Fujihara, R. Okamura, T. Wada, and K. Tanaka, "Coordination ability of 1,10-phenanthroline-5,6-dione: syntheses and redox behavior of a $\mathrm{Ru}$ (II) complex with an o-quinoid moiety and of bridged $\mathrm{Ru}(\mathrm{II})-\mathrm{M}(\mathrm{II})$ complexes $(\mathrm{M}=\mathrm{Pd}, \mathrm{Pt})$," Dalton Transactions, no. 16, pp. 3221-3226, 2003.

[34] H. Shahroosvand, M. Khorasani-Motlagh, M. Noroozifar, M. Shabani, A. Fyezbakhsh, and M. Abdouss, "Synthesis and characterisation of $\mathrm{TiO}_{2}$ nanoparticle with polypyridily complexes for using in solar cells," International Journal of Nanomanufacturing, vol. 5, no. 3-4, pp. 352-365, 2010.

[35] H. Shahroosvand, M. Khorasani-Motlagh, M. Noroozifar, M. Shabani, A. R. Fyezbakhsh, and M. Abdouss, "Preparation and reactivity of $\mathrm{MoO}_{2}$ nanoparticle based on polypyridily complexes," Solid State Science in Proceedings of the 3nd Conference on Chemistry, pp. 102, Islamic Azad University, Varamin-Pishva Branch, Varamin, Iran, 2008.

[36] H. Shahroosvand, M. Shabani, M. Korasani-Motlagh, and A. R. Feyzbakhsh, "Synthesis and characterization of novel 
complexes of copper with polypyriyil ligands and $\mathrm{TiO}_{2}$ nanoparticle for using solar cells," in Proceedings of the 2nd Conference on Nanostructures, pp. 58-59, Kish Island, Iran, 2008.

[37] P. Qu, D. W. Thompson, and G. J. Meyer, "Temperaturedependent electron injection from $\mathrm{Ru}(\mathrm{II})$ polypyridyl compounds with low lying ligand field states to titanium dioxide," Langmuir, vol. 16, no. 10, pp. 4662-4671, 2000.

[38] P. Qu and G. J. Meyer, "Proton-controlled electron injection from molecular excited states to the empty states in nanocrystalline $\mathrm{TiO}_{2}$," Langmuir, vol. 17, no. 21, pp. 6720-6728, 2001.

[39] A. S. Polo, M. K. Itokazu, and N. Y. Murakami Iha, "Metal complex sensitizers in dye-sensitized solar cells," Coordination Chemistry Reviews, vol. 248, no. 13-14, pp. 1343-1361, 2004.

[40] H. Zabri, I. Gillaizeau, C. A. Bignozzi et al., "Synthesis and comprehensive characterizations of new cis-RuL $2 \mathrm{X}_{2}$ ( $\mathrm{X}=$ CI, CN, and NCS) sensitizers for nanocrystalline $\mathrm{TiO}_{2}$ solar cell using bis-phosphonated bipyridine ligands (L)," Inorganic Chemistry, vol. 42, no. 21, pp. 6655-6666, 2003.

[41] J. Ohlsson, H. Wolpher, A. Hagfeldt, and H. Grennberg, "New dyes for solar cells based on nanostructured semiconducting metal oxides. Synthesis and characterisation of ruthenium(II) complexes with thiol-substituted ligands," Journal of Photochemistry and Photobiology A, vol. 148, no. 1-3, pp. 41-48, 2002.

[42] Y. Hou, P. Xie, K. Wu, J. Wang, B. Zhang, and Y. Cao, "Synthetic control of the photophysical and photoelectrochemical properties of ruthenium(II) polypyridyl complexes," Solar Energy Materials and Solar Cells, vol. 70, no. 2, pp. 131-139, 2001.

[43] T. A. Heimer, S. T. D’Arcangelis, F. Farzad, J. M. Stipkala, and G. J. Meyer, "An acetylacetonate-based semiconductorsensitizer linkage," Inorganic Chemistry, vol. 35, no. 18, pp. 5319-5324, 1996.

[44] K. Kakiuchi, E. Hosono, and S. Fujihara, "Enhanced photoelectrochemical performance of $\mathrm{ZnO}$ electrodes sensitized with N-719," Journal of Photochemistry and Photobiology A, vol. 179, no. 1-2, pp. 81-86, 2006.

[45] J. B. Baxter, A. M. Walker, K. van Ommering, and E. S. Aydil, "Synthesis and characterization of $\mathrm{ZnO}$ nanowires and their integration into dye-sensitized solar cells," Nanotechnology, vol. 17, no. 11, pp. 5304-5312, 2006.

[46] K. Nakamato, Infrared and Raman Spectra of Inorganic and Coordination Compounds Part II: Application in Coordination, Organometallic and Bioinorganic, John Wiley \& Sons, New York, NY, USA, 1997.

[47] C. Klein, M. K. Nazeeruddin, D. Di Censo, P. Liska, and M. Grätzel, "Amphiphilic ruthenium sensitizers and their applications in dye-sensitized solar cells," Inorganic Chemistry, vol. 43, no. 14, pp. 4216-4226, 2004.

[48] M. Hosokawa, K. Nogi, M. Naito, and T. Yokoyama, "A dye-sensitaezed solar cell utilizing metal nanoparticle," in Nanoparticle Technology Handbook, chapter 5, pp. 438-439, Elsevier, 2007.

[49] S. M. Zakeeruddin, M. K. Nazeeruddin, P. Pechy et al., "Molecular engineering of photosensitizers for nanocrystalline solar cells: synthesis and characterization of $\mathrm{Ru}$ dyes based on phosphonated terpyridines," Inorganic Chemistry, vol. 36, no. 25, pp. 5937-5946, 1997.

[50] H. Rensmo, K. Keis, H. Lindström et al., "High light-to-energy conversion efficiencies for solar cells based on nanostructured ZnO electrodes," Journal of Physical Chemistry B, vol. 101, no. 14, pp. 2598-2601, 1997.
[51] K. Keis, J. Lindgren, S. E. Lindquist, and A. Hagfeldt, "Studies of the adsorption process of Ru complexes in nanoporous $\mathrm{ZnO}$ electrodes," Langmuir, vol. 16, no. 10, pp. 4688-4694, 2000.

[52] G. Redmond, D. Fitzmaurice, and M. Graetzel, "Visible light sensitization by cis-bis(thiocyanato)bis(2,2' -bipyridyl$4,4^{\prime}$-dicarboxylato) ruthenium(II) of a transparent nanocrystalline $\mathrm{ZnO}$ film prepared by sol-gel techniques," Chemistry of Materials, vol. 6, no. 5, pp. 686-691, 1994.

[53] J. B. Asbury, Y. Wang, and T. Lian, "Multiple-exponential electron injection in $\mathrm{Ru}(\mathrm{dcb} p \mathrm{f}) 2(\mathrm{SCN}) 2$ sensitized $\mathrm{ZnO}$ nanocrystalline thin films," Journal of Physical Chemistry B, vol. 103, no. 32, 1999. 


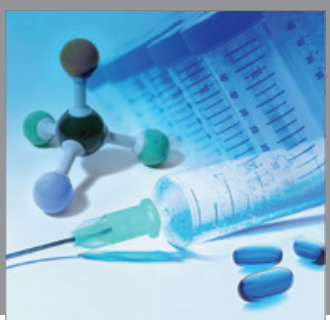

International Journal of

Medicinal Chemistry

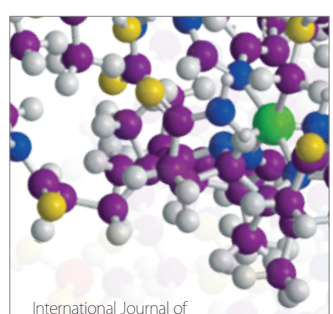

Carbohydrate Chemistry

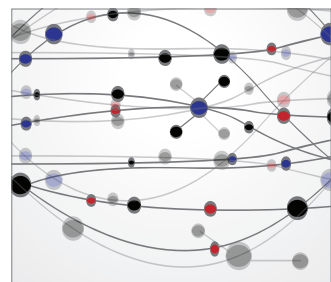

The Scientific World Journal
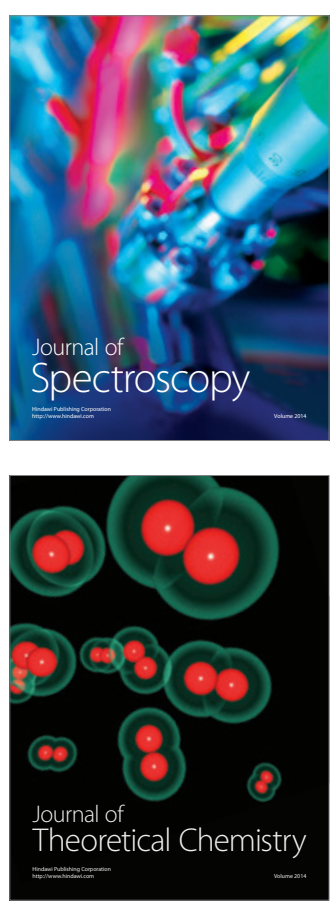
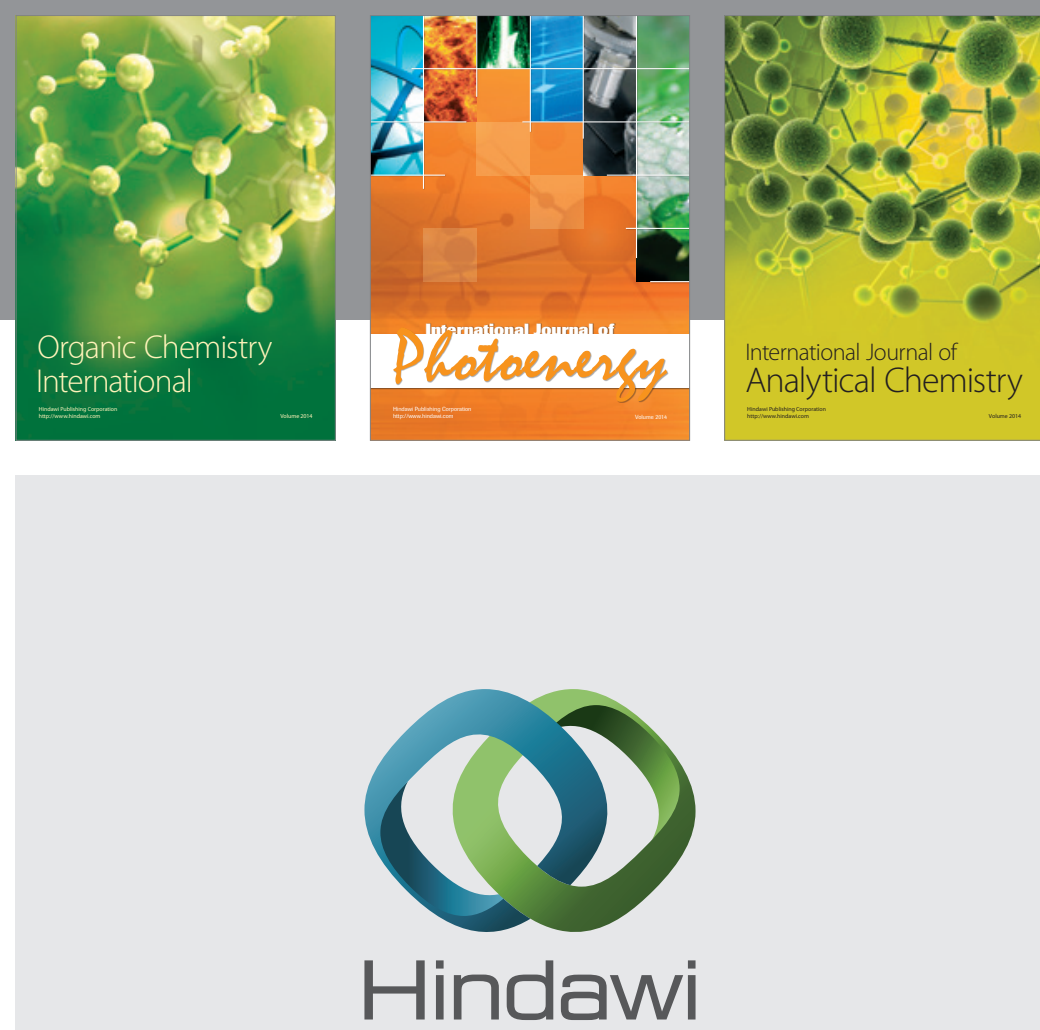

Submit your manuscripts at

http://www.hindawi.com
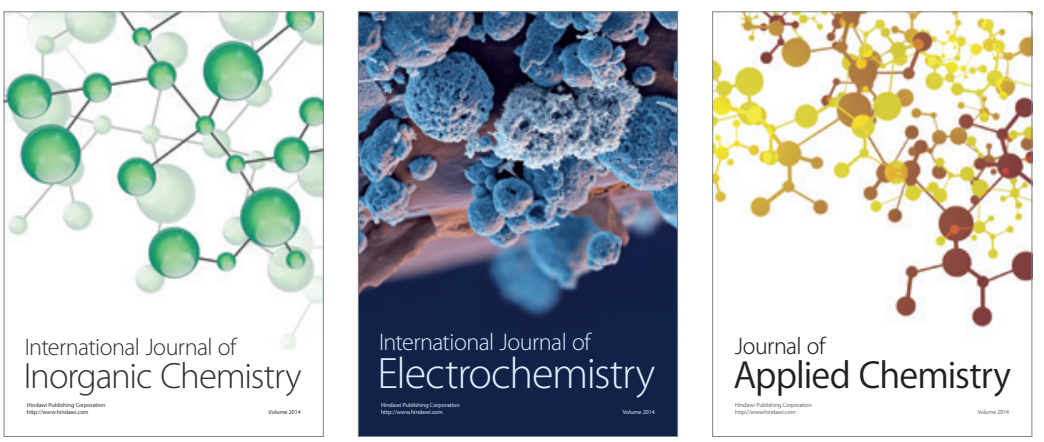

Journal of

Applied Chemistry
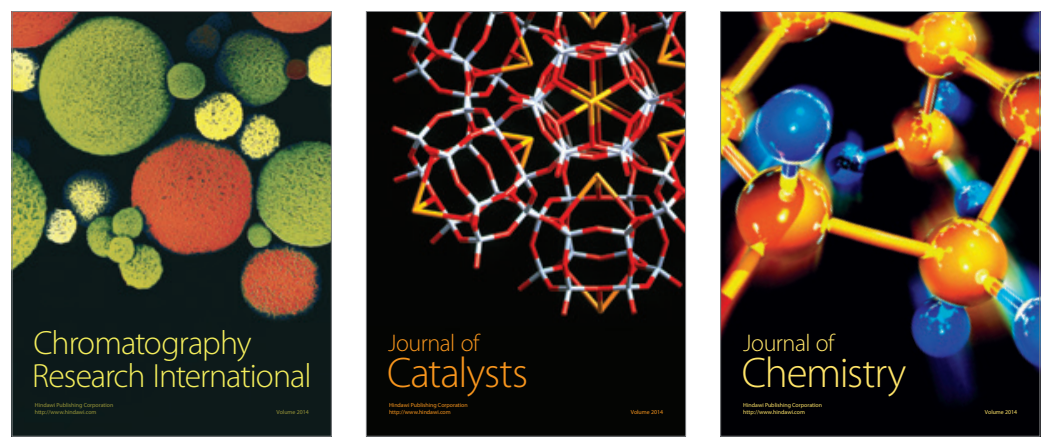
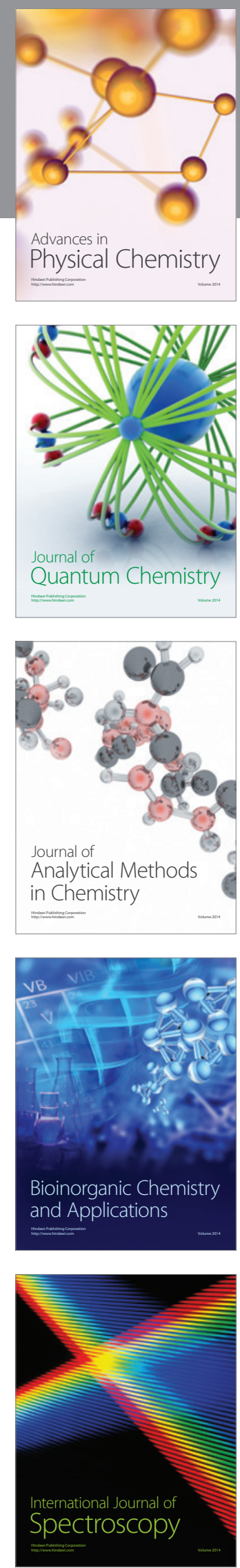